\title{
Transgenic Mice Expressing High Levels of Human Apolipoprotein B Develop Severe Atherosclerotic Lesions in Response to a High-Fat Diet
}

\author{
Deborah A. Purcell-Huynh, ** Robert V. Farese, Jr., ${ }^{\star * 5}$ David F. Johnson, ${ }^{* \neq}$ Laura M. Flynn, * Vincenzo Pierotti, * \\ Dale L. Newland, ${ }^{*}$ MacRae F. Linton, ${ }^{\star \neq}$ David A. Sanan, ${ }^{\star \star}$ and Stephen G. Young ${ }^{\star \neq \$}$ \\ ${ }^{*}$ Gladstone Institute of Cardiovascular Disease, San Francisco, California 94141-9100; and ${ }^{\ddagger}$ Cardiovascular Research Institute and \\ ${ }^{\S}$ Department of Medicine, University of California, San Francisco, California 94143
}

\begin{abstract}
We previously generated transgenic mice expressing human apolipoprotein (apo-) $B$ and demonstrated that the plasma of chow-fed transgenic animals contained markedly increased amounts of LDL (Linton, M. F., R. V. Farese, Jr., G. Chiesa, D. S. Grass, P. Chin, R. E. Hammer, H. H. Hobbs, and S. G. Young 1992. J. Clin. Invest. 92:3029-3037). In this study, we fed groups of transgenic and nontransgenic mice either a chow diet or a diet high in fat (16\%) and cholesterol $(1.25 \%)$. Lipid and lipoprotein levels were assessed, and after 18 wk of diet, the extent of aortic atherosclerotic lesions in each group of animals was quantified. Compared with the female transgenic mice on the chow diet, female transgenic mice on the high-fat diet had higher plasma levels of cholesterol $(312 \pm 17$ vs $144 \pm 7 \mathrm{mg} / \mathrm{dl} ; P$ $<0.0001)$ and human apo-B $(120 \pm 8$ vs $84 \pm 3 \mathrm{mg} / \mathrm{dl} ; P$ $<0.0001$ ). The higher human apo-B levels were due to increased plasma levels of human apo-B48; the human apoB100 levels did not differ in animals on the two diets. In mice on the high-fat diet, most of the human apo-B48 and apo-B100 was found in LDL-sized particles. Compared with nontransgenic mice on the high-fat diet, the transgenic animals on the high-fat diet had significantly increased levels of total cholesterol (312 \pm 17 vs $230 \pm 19 \mathrm{mg} / \mathrm{dl} ; P<0.0001)$ and non-HDL cholesterol $(283 \pm 17$ vs $193 \pm 19 \mathrm{mg} / \mathrm{dl} ; P$ $<0.0001$ ). The extent of atherosclerotic lesion development within the ascending aorta was quantified by measuring total lesion area in 60 progressive sections, using computerassisted image analysis. Neither the chow-fed transgenic mice nor the chow-fed nontransgenic mice had significant atherosclerotic lesions. Nontransgenic animals on the highfat diet had relatively small atherosclerotic lesions $(<15,000$ $\boldsymbol{\mu m}^{2}$ /section ), almost all of which were confined to the proximal $400 \mu \mathrm{m}$ of the aorta near the aortic valve. In contrast, transgenic animals on the high-fat diet had extensive athero-
\end{abstract}

Address correspondence to Stephen G. Young, Gladstone Institute of Cardiovascular Disease, P.O. Box 419100, San Francisco, CA 941419100. Phone: 415-826-7500; FAX: 415-285-5632. MacRae F. Linton's current address is Vanderbilt University Medical Center, Division of Endocrinology, Medical Center North AA4026, Nashville, TN 372322250.

Received for publication 28 October 1994 and in revised form 23 December 1994.

J. Clin. Invest.

(c) The American Society for Clinical Investigation, Inc.

$0021-9738 / 95 / 05 / 2246 / 12 \$ 2.00$

Volume 95, May 1995, 2246-2257 sclerotic lesions ( $>160,000 \mu \mathrm{m}^{2} /$ section) that were widely distributed throughout the proximal 1,200 $\mu \mathrm{m}$ of the aorta. Thus, human apo-B expression, in the setting of a diet rich in fats, causes severe atherosclerosis in mice. (J. Clin. Invest. 1995. 95:2246-2257.) Key words: transgenic mice • atherosclerosis - apolipoprotein B - cholesterol • low density lipoproteins

\section{Introduction}

Considerable evidence indicates that the apo-B-containing lipoproteins (e.g., VLDL, intermediate density lipoproteins [IDL] ${ }^{1}$ LDL, lipoprotein [a]) are atherogenic (1). Feeding a diet rich in fats and cholesterol to nonhuman primates $(2,3)$ as well as certain strains of mice $(4,5)$ results in elevated levels of the apo-B-containing lipoproteins, and is accompanied by the development of atherosclerotic lesions in the large arteries. Moreover, human lipoprotein disorders associated with retarded clearance of the apo-B-containing lipoproteins (type III hyperlipoproteinemia [6], familial defective apolipoprotein B100 [7], and familial hypercholesterolemia [8]) are characterized by elevated levels of the apo-B-containing lipoproteins and premature atherosclerotic disease. In recent years, several groups have used homologous recombination in mouse embryonic stem cells to generate apo-E-deficient mice $(9,10)$ and LDL receptor-deficient mice (11). Both of these targeted mutations interfere with the clearance of apo-B-containing lipoproteins from the plasma; in both of these animal models, the plasma levels of the apo-B-containing lipoproteins are elevated and there is increased susceptibility to the development of atherosclerosis $(12-15)$.

To study the metabolic and pathologic consequences of an increased rate of production of the apo-B-containing lipoproteins, we recently generated transgenic mice expressing high levels of human apo-B (16). The mice were generated using a 79.5-kb genomic DNA fragment spanning the entire human apo-B gene; interestingly, the human apo-B transgene was expressed at high levels in the liver, but not in the intestine (16, 17). On a chow diet, the human apo-B100 levels in the plasma of hemizygous transgenic animals were $50-60 \mathrm{mg} / \mathrm{dl}$, nearly equivalent to the levels in normolipidemic humans. The distribution of human apo-B100 in the plasma lipoproteins of the chow-fed transgenic mice was virtually identical to the distribution of apo-B100 in human plasma, with $>90 \%$ of the human apo-B100 in the LDL and the remainder in the VLDL and IDL. Because the human apo-B-containing lipoproteins in the

1. Abbreviation used in this paper: IDL, intermediate density lipoprotein. 
transgenic mouse plasma were enriched in both cholesterol and triglycerides, the transgenic animals had significantly elevated plasma levels of both cholesterol and triglycerides (16).

In the human apo-B transgenic mice, the high levels of LDL in chow-fed hemizygous mice were obviously due, at least in part, to the overproduction of apo-B in the liver (16). In considering how the human apo-B mice might respond to a diet rich in fats and cholesterol, we found it difficult to make a priori predictions. The fact that the transgenic animals already had relatively high levels of human apo-B on a chow diet suggested that they might develop very high levels of apo-B in the setting of a high-fat diet. Marked elevations in apo-B levels are observed in other mammals when they are placed on a high-fat diet (2). On the other hand, it seemed possible that having a full complement of apo-E in the plasma, as well as LDL receptors in the liver, might prevent a large increase in apo-B and cholesterol levels. Similarly, one could imagine that the high levels of apoB mRNA editing activity in the mouse liver, which is responsible for the production of apo-B48-containing lipoproteins, might serve to protect mice from severe hypercholesterolemia (18). We also found it difficult to make specific predictions about the susceptibility of the human apo-B transgenic mice to aortic atherosclerosis. Because LDL is considered atherogenic, it seemed possible that the relatively high levels of LDL cholesterol in the chow-fed animals would render them susceptible to atherosclerosis. Alternatively, it would be reasonable to postulate that the development of atherosclerosis in these animals might require a high-fat diet, which, at least in the C57BL/6 strain, is accompanied by a decrease in HDL cholesterol levels (19-21) and an induction of a variety of inflammatory genes (22). In this paper, we report studies that address these important issues. We have thoroughly characterized the response of the human apo-B transgenic animals to a diet rich in fats and cholesterol, and we quantify the extent of aortic atherosclerosis in groups of transgenic and nontransgenic mice fed either chow or high-fat diets.

\section{Methods}

Animals and diets. C57BL/6 mice were obtained from the Jackson Laboratory (Bar Harbor, ME). The human apo-B transgenic founder animal 1102 (a C57BL/6 $\times \mathrm{SJL} \mathrm{F}_{2}$ animal) (16) was backcrossed with a C57BL/6 male animal; the first litter yielded three male transgenic animals. These three males were backcrossed with C57BL/6 females to produce all of the human apo-B transgenic animals used in this study. All of the transgenic animals were hemizygous for the transgene. The nontransgenic controls in these studies were littermates of the transgenic animals. Thus, the genomes of both the transgenic and the nontransgenic animals were $87.5 \%$ identical to that of C57BL/6 mice.

All mice were weaned at $21 \mathrm{~d}$ and housed in a full barrier transgenic facility on a 12-h light-dark cycle, with free access to food and water. Blood samples were collected from the retrooribital sinus (at 5 wk of age) in serum separator tubes containing EDTA, and plasma was obtained by centrifugation. Transgenic animals were identified by a monoclonal antibody-based sandwich RIA for human apo-B100 (16). A total of 24 female transgenic mice, 6 male transgenic mice, 24 female nontransgenic mice, and 6 male nontransgenic mice were placed on a high-fat diet between 5 and 8 wk of age; an identical number of transgenic and nontransgenic animals were continued on a chow diet (Breeder Chow; Ralston Purina Co., St. Louis, MO). The synthetic high-fat diet (purchased from ICN Biomedicals, Inc., Aurora, $\mathrm{OH}$ ) contained $15 \%$ cocoa butter, $1 \%$ corn oil, $50 \%$ sucrose, $20 \%$ casein, $1.25 \%$ cholesterol, $0.5 \%$ sodium cholate, $4.82 \%$ alphacel nonnutritive bulk, $5 \%$
American Institute of Nutrition mineral mix, $1 \%$ American Institute of Nutrition vitamin mix, $1 \%$ choline chloride, $0.3 \%$ DL-methionine, and $0.13 \%$ vitamin $\mathrm{E}(250 \mathrm{U} / \mathrm{g})$. Mice were maintained on the diets for 18 wk before they were killed for pathologic studies.

Lipid measurements. Total and HDL cholesterol levels, as well as triglyceride levels, were determined for all mice at the initiation of the study and after 5 wk of diet. Total plasma cholesterol levels and HDL cholesterol levels were measured in quadruplicate, using a colorimetric assay (Abbott Spectrum kit; Abbott Laboratories Diagnostics Division, Abbott Park, IL). The HDL cholesterol was measured after the precipitation of the apo-B-containing lipoproteins with polyethylene glycol8000 (23). Briefly, $12.5 \mu \mathrm{l}$ of plasma was mixed with $12.5 \mu \mathrm{l}$ of 0.9 $\mathrm{M} \mathrm{NaCl}$ and $25 \mu \mathrm{l}$ of polyethylene glycol- 8000 (200 g/liter) in a 0.2 $\mathrm{M}$ glycine buffer, $\mathrm{pH} 10$, vortexed, and the mixture was incubated at room temperature for $15 \mathrm{~min}$. The samples were centrifuged for $5 \mathrm{~min}$ in a microcentrifuge; $30 \mu \mathrm{l}$ of the supernatant fluid from the top of the tube was transferred to a new tube for HDL cholesterol determination. Triglyceride concentrations were determined, using the Triglyceride/ GB kit from Boehringer Mannheim Biochemicals (Indianapolis, IN). The accuracy of the lipid assays was monitored in each assay using Reference Material Serum Lipids (\#RM016) from the College of American Pathologists (Ciba Corning Diagnostics Corp., Irvine, CA).

Analysis of the lipid and apolipoprotein distribution by chromatographic separation of plasma lipoproteins. To analyze the distribution of cholesterol, triglycerides, and human and mouse apo-B within the plasma, plasma samples were fractionated by chromatography on a Superose 6 10/50 column (Pharmacia LKB Biotechnology, Piscataway, $\mathrm{NJ})$. For these analyses, $20 \mu \mathrm{l}$ of plasma from each of six mice was mixed with $130 \mu \mathrm{l}$ of PBS. Before loading the $250-\mu \mathrm{l}$ sample onto the column, the sample was spun for $5 \mathrm{~min}$ in a microcentrifuge to remove any particulate material. The column was eluted at a flow rate of 0.5 $\mathrm{ml}$ per $\mathrm{min}$, and $600.5-\mathrm{ml}$ fractions were collected; $100-\mu \mathrm{l}$ aliquots from each fraction were used for the measurement of cholesterol and triglycerides. To determine the distribution of apo-B48 and apo-B100 within the plasma lipoproteins, 15- $\mu$ l aliquots from two consecutive column fractions were combined and then subjected to size-fractionation on 3-12\% gradient SDS-polyacrylamide gels. The separated proteins were then electrophoretically transferred to a sheet of nitrocellulose membrane for Western blot analysis (24). Human apo-B was detected using a ${ }^{125}$-labeled mAb specific for human apo-B, C1.4 (25). Mouse apo-B was detected using a rabbit anti-mouse apo-B polyclonal antibody (provided by Dr. Helen Hobbs, Dallas, TX), followed by donkey anti-rabbit IgG conjugated to horseradish peroxidase (Bio-Rad Laboratories, Hercules, CA). The binding of the antibody was detected using an enhanced chemiluminescence kit (Amersham Corp., Arlington Heights, IL). Because preliminary experiments showed that the rabbit antibody to mouse apo-B bound human apo-B100 to a small degree, we added $100 \mu \mathrm{l}$ of human serum to the primary antibody incubation solution. This antibody absorption step eliminated the binding of the antibody to human apo-B.

Agarose gel electrophoresis. Lipoproteins were separated on agarose gels, using the Electrophoresis Systems ${ }^{\mathrm{TM}}$ Lipoprotein Kit/8 (Ciba Corning Diagnostics Corp.). Briefly, $2 \mu \mathrm{l}$ of plasma was loaded into each well of a precast $1 \%$ agarose gel. The plasma samples were electrophoresed in universal buffer ( $43 \mathrm{mM}$ sodium barbital, $7 \mathrm{mM}$ barbital) for $35 \mathrm{~min}$ and then dried in a $50^{\circ} \mathrm{C}$ oven for $1 \mathrm{~h}$. Gels were then stained with Fat Red 7B for 5 min, rinsed with 70\% methanol, and dried again at $50^{\circ} \mathrm{C}$.

Antibodies and immunoassays. Measurement of total human apoB levels (apo-B100 and apo-B48) and human apo-B100 levels were performed on all of the male and female transgenic mice. Quantitation of human apo-B100 in transgenic plasma was performed using a solidphase competitive RIA (16). For this assay, Immulon (A/S Nunc, Roskilde, Denmark) high-binding, flat-bottom, 96-well plates were coated overnight at $4^{\circ} \mathrm{C}$ with $50 \mu \mathrm{l}$ per well of PBS containing immunopurified $\mathrm{mAb}(2 \mu \mathrm{g} / \mathrm{ml})$. Antibody MB47 binds near human apo-B100 amino acid residue 3500 and therefore binds to human apo-B100, but 
not to apo-B48. Antibody MB47 does not bind to mouse apo-B100. After the plates were coated with antibody MB47, they were washed six times with SPRIA (PBS containing $0.1 \%$ RIA grade BSA [Sigma Chemical Co., St. Louis, MO], $0.05 \%$ Tween-20, and $0.08 \%$ sodium azide). The remaining binding sites were blocked for $2 \mathrm{~h}$ with SPRIA containing $2 \%$ BSA (SPRIA-BSA). After again washing the plates six times with SPRIA, transgenic mouse plasma and the plasma from a normolipidemic human subject were diluted in SPRIA-BSA, and $25 \mu \mathrm{l}$ of each dilution was added in triplicate to the plates. Then, $25 \mu \mathrm{l}$ of a fixed concentration of ${ }^{125} \mathrm{I}$-labeled human LDL $(350,000 \mathrm{cpm} /$ well $)$ was added to each well. The human LDL was prepared from human plasma by ultracentrifugation and radioiodinated by the lactoperoxidase method to a sp act of $5,000-10,000 \mathrm{cpm} / \mathrm{ng}$. The plates were incubated at $4^{\circ} \mathrm{C}$ overnight and washed six times with SPRIA; each well was then counted in a gamma counter. The standard curve for the assay was constructed from dilutions of a human plasma sample that had an apo-B concentration of $60 \mathrm{mg} / \mathrm{dl}$. The concentration of human apo-B in the transgenic plasma samples was determined by a standard curve and a linear regression of $\operatorname{logit} B / B_{0}$ vs the $\log$ of the standard concentration, where $B$ and $B_{0}$ are the specific counts bound in the presence and absence of competitor, respectively. The total human apo-B level (human apoB100 and human apo-B48) was measured using a competitive RIA that was identical to this assay except that the 96-well plates were initially coated with PBS containing $2 \mu \mathrm{g} / \mathrm{ml}$ of mAb 1D1, which binds to both apo-B48 and apo-B100 (26) (near apo-B amino acid 500). Antibody $1 \mathrm{D} 1$ does not bind to mouse apo-B. Mouse apo-B plasma concentrations were measured on seven female mice in each group using a rocket immunoassay that was established in the laboratory of Dr. George Melchior (The Upjohn Co., Kalamazoo, MI) (23). The rabbit anti-mouse apo-B antibody used in the rocket immunoassay did not detect human apo-B.

Apo-B mRNA editing. To analyze the extent of editing of the human apo-B mRNA and the mouse apo-B mRNA, we prepared cDNA from the kidney, intestine, and liver of transgenic and nontransgenic animals. Animals were killed either after a 14-h fast or within $1 \mathrm{~h}$ of the removal of food from their cages. Mouse organs were harvested directly into liquid nitrogen, and total cellular RNA was prepared using the Totally RNA purification kit (Stratagene Inc., La Jolla, CA). To prepare cDNA for the primer extension assays, 5-10 $\mu \mathrm{g}$ of the total RNA was first treated with $0.5 \mu \mathrm{l}$ of DNase I (RNase-free, from Boehringer Mannheim Biochemicals) for $10 \mathrm{~min}$ at $37^{\circ} \mathrm{C}$. The reaction was terminated by incubation at $90^{\circ} \mathrm{C}$ for $10 \mathrm{~min}$. The DNase I pretreatment of the RNA was invariably successful in eliminating genomic DNA contamination of the RNA; with the DNase-treated RNA as a substrate, it was impossible to enzymatically amplify short segments of the apo-B cDNA or gene using Thermus aquaticus (Taq) polymerase. After pretreatment of the RNA with DNase I, cDNA was synthesized from 5-10 $\mu \mathrm{g}$ of RNA using a mouse and human apo-B-specific oligonucleotide (5' CCACATTTTGAATCCAAGATGCAGTACTACT 3', corresponding to human apo-B cDNA nucleotides 6885-6855) (27), and $1 \mu \mathrm{l}$ of StrataScript RNase $\mathrm{H}^{-}$reverse transcriptase, according to the instructions provided in the Stratascript RT-PCR kit (Stratagene). Short (278-bp) segments of mouse and human apo-B cDNA were amplified from the singlestranded cDNA using Taq polymerase (Boehringer Mannheim Biochemicals) and the same species-specific apo-B oligonucleotide primers that we described previously (27). To measure the extent of apo-B editing, the amplified segments of mouse apo-B cDNA and human apoB cDNA were analyzed using a primer extension assay (28).

Preparation of aortic sections. In this study, we performed comprehensive atherosclerosis quantification studies on the first 12 female mice of each group that completed 18 wk of diet. Atherosclerosis quantification studies were performed on five of the six male mice (One male in each group died before the end of the 18-wk diet period.). Mice were anesthetized with Metofane (methoxyflurane); (Pitman-Moore, Inc., Mundelein, IL). Hearts were exposed by thoracotomy; after nicking of the inferior vena cava, the animals were perfused via ventricular puncture, first with PBS to flush out the blood, and then with $10 \%$ neutral buffered formalin for $5 \mathrm{~min}$ to fix the aorta. The hearts (and the thoracic aorta) were dissected away from the thorax and stored in $10 \%$ formalin at $4^{\circ} \mathrm{C}$ before sectioning. The thoracic aorta was then cut away from the rest of the heart $\sim 1 \mathrm{~mm}$ below the aortic valve and embedded in Tissue-Tek OCT compound (Miles, Inc., Elkhart, IN) in cryostat molds. Samples were snap frozen by immersion in liquid nitrogen and stored at $-20^{\circ} \mathrm{C}$. The sectioning strategy was modified from that of Paigen et al. (29) as follows. Sequential sections $10-\mu \mathrm{m}$ thick were taken using a Reichert 2800 cryostat (Reichert Scientific Instruments, Buffalo, NY) and viewed unstained until the aortic valve leaflets appeared. From this point, every other section was collected until $1.2 \mathrm{~mm}$ of aorta had been traversed; thus, 60 progressive sections were collected at $20-\mu \mathrm{m}$ intervals. Thus, we examined both the aortic sinuses and the region distal to the orifices of the coronary arteries. The sections, mounted five per slide, were stained in $0.5 \%$ Oil Red $\mathrm{O}$ in propylene glycol for $4 \mathrm{~h}$ and counterstained in Mayer's hematoxylin for $1 \mathrm{~min}$.

Image analysis. Image analysis was performed by one of us (D. A. Purcell-Huynh) who was blinded to the study group. Images were examined using a color video camera (CCD-IRIS; Sony Corp., Tokyo, Japan) mounted by means of an Optem $2 / 3$ photo-eyepiece adaptor to one ocular of a light microscope (Standard RA; Carl Zeiss, Inc., Thornwood, NY). The images were captured into the framestores of an Image-1/AT image analysis system (software version 4.03a; Universal Imaging Corp., West Chester, PA). Color thresholding was performed to delimit the Oil Red O-stained lesion followed by area measurement $\left(\mu \mathrm{m}^{2}\right)$ via automated pixel counting. A calibration slide was used to scale the image analysis system. The total lesion area for each of 60 sections per mouse was measured.

Histology. To examine the morphology of lesions, sections from wax-embedded material were stained with hematoxylin and eosin, and also with Masson's trichrome stain (Lillie's modification) to detect collagen.

Electron microscopy. For thin sectioning electron microscopy, aortas were fixed in $2.5 \%$ glutaraldehyde in $0.1 \mathrm{M}$ sodium cacodylate buffer $\mathrm{pH} 7.4$ for $2 \mathrm{~h}$, postfixed in osmium tetroxide in $0.1 \mathrm{M}$ sodium cacodylate ( $\mathrm{pH}$ 7.4) for $1 \mathrm{~h}$, dehydrated in a graded ethanol series, and embedded in POLY/BED 812 epoxy resin (Polysciences, Inc., Warrington, PA). Semithin sections $(0.5 \mu \mathrm{m})$ cut on a diamond knife and stained with toluidine blue were used to image aortic lesions by light microscopy at high magnification. Ultrathin sections (60-90 nm thick) were cut on an ultramicrotome (Ultracut E; Reichert Scientific Instruments) and stained with uranyl acetate and lead citrate. Specimens were examined in a transmission electron microscope ( $100 \mathrm{Cx}$; JEOL USA, Peabody, MA).

Statistical analysis. Measurements of lipid, lipoprotein, and apoB levels as well as atherosclerosis lesion areas are presented as the mean \pm SEM. Means, standard errors, and ANOVA, (i.e., $P$ values) were determined using the Statview II ${ }^{\mathrm{TM}}$ application for the Macintosh computer (Abacus Concepts Inc., Berkeley, CA). Statistical significance for differences in lesion area between transgenic and nontransgenic mice was determined using two-factor repeated measure ANOVA analysis.

\section{Results}

Apolipoprotein B levels and distribution. In female human apo$B$ transgenic mice on a chow diet, the mean level of total human apo-B (measured with an RIA that detects both human apoB100 and human apo-B48) was $83.7 \mathrm{mg} / \mathrm{dl}$, whereas the mean human apo-B100 level in the same animals was $62.9 \mathrm{mg} / \mathrm{dl}$ (Table I). In female transgenic animals on a high-fat diet, the total apo-B levels increased $\sim 44 \%$, to $120.2 \mathrm{mg} / \mathrm{dl}$, but the human apo-B100 levels in these mice were no higher than those in the chow-fed mice. The findings in the male transgenic mice were similar: the total human apo-B levels increased on the high-fat diet, whereas the apo-B100 levels remained unchanged. 
Table I. Lipid, Lipoprotein, and Apo-B Measurements in Transgenic and Nontransgenic Mice

\begin{tabular}{|c|c|c|c|c|}
\hline & Transgenic chow diet & Transgenic high-fat diet & Nontransgenic chow diet & Nontransgenic high-fat diet \\
\hline \multicolumn{5}{|l|}{ Female mice } \\
\hline Total cholesterol & $144.2 \pm 7.4$ & $311.8 \pm 17.1$ & $103.4 \pm 4.2$ & $230.2 \pm 18.8$ \\
\hline HDL cholesterol & $60.1 \pm 1.7^{*}$ & $28.6 \pm 2.2$ & $67.4 \pm 2.0^{8}$ & $37.4 \pm 2.3^{*}$ \\
\hline Non-HDL cholesterol & $84.2 \pm 8.4$ & $283.3 \pm 17.2$ & $35.6 \pm 3.0$ & $192.6 \pm 18.6$ \\
\hline Triglyceride & $71.4 \pm 5.0$ & $13.8 \pm 1.3$ & $24.7 \pm 2.7$ & $15.4 \pm 2.1$ \\
\hline Human total apo-B & $83.7 \pm 2.9 *$ & $120.2 \pm 8.0$ & 0 & 0 \\
\hline Human apo-B100 & $62.9 \pm 2.9^{\ddagger}$ & $56.9 \pm 3.7$ & 0 & 0 \\
\hline \multicolumn{5}{|l|}{ Male mice } \\
\hline Total cholesterol & $154.4 \pm 9.9$ & $259.7 \pm 25.7$ & $118.3 \pm .9$ & $234.2 \pm 43.9$ \\
\hline HDL cholesterol & $76.1 \pm 2.2 *$ & $36.3 \pm 5.3$ & $80.6 \pm .9^{8}$ & $61.9 \pm 6.4 *$ \\
\hline Non-HDL cholesterol & $78.3 \pm 9.4$ & $223.4 \pm 24.2$ & $37.7 \pm 2.4$ & $172.3 \pm 48.6$ \\
\hline Triglyceride & $95.0 \pm 13.0$ & $20.1 \pm 3.1$ & $38.5 \pm 10.1$ & $12.5 \pm 1.6$ \\
\hline Human total apo-B & $39.9 \pm 3.7 *$ & $75.5 \pm 11.5$ & 0 & 0 \\
\hline Human apo-B100 & $.6 .4 \pm 4.2^{\ddagger}$ & $40.9 \pm 5.6$ & 0 & 0 \\
\hline
\end{tabular}

Plasma lipid, lipoprotein, and apo-B measurements $(\mathrm{mg} / \mathrm{dl})$ formed after $5 \mathrm{wk}$ on either a chow or a high-fat diet. Statistically significant differences between females and males are indicated as follows: ${ }^{*} P<0.0001 ;{ }^{\ddagger} P=0.0002$; and ${ }^{\S} P=0.0054$. Measurements were performed on 24 female mice in each group and 6 male mice in each group. Values are reported as the mean \pm SEM.

Male transgenic mice did, however, have $52 \%$ lower total human apo-B levels $(P<0.0001)$ and $42 \%$ lower human apoB100 levels than the female mice $(P<0.0001)$ (Table I).

The finding that total apo-B levels increased in response to a high-fat diet while apo-B100 levels were unchanged implied that the high-fat diet may have resulted in increased plasma levels of human apo-B48. To test this possibility, we obtained plasma samples after a 14-h fast, fractionated the plasma samples on a Superose 6/60 column, and then performed Western blot analysis of the fractions, using the human apo-B-specific $\mathrm{mAb}, \mathrm{C} 1.4$. These studies confirmed our suspicion that the highfat diet resulted in markedly increased levels of human apoB48 (Fig. $1 \mathrm{~A}$ ). These chromatographic studies also permitted us to compare the distribution of human apo-B100 and apoB48 on the two diets. In the chow-fed transgenic mice, virtually all of the human apo-B100 was in the LDL fraction; the human apo-B48 was more widely distributed, but most was in LDLsized particles. On the high-fat diet, most of the human apoB100 was again found in the LDL-sized particles. The apoB100 in the plasma of animals on the high-fat diet was, however, found in slightly larger particles than in the chow-fed animals. Interestingly, the vast majority of the human apo-B48 was also in LDL-sized particles, with only small amounts of apo-B48 in the VLDL and IDL. To ensure that this finding was not a peculiarity of human apo-B48, we performed Western blots with a rabbit antibody specific for mouse apo-B. In the transgenic animals fed either the chow diet or the high-fat diet, there were no differences in the distributions of the mouse and human apo-B proteins (Fig. $1, A$ and $B$ ). In the nontransgenic animals, we also found that most of the mouse apo-B48 was in LDL-sized particles (data not shown).

The human apo-B mRNA is known to be edited by the mouse apo-B mRNA editing machinery (27). We wanted to determine whether the high levels of human apo-B mRNA in the liver of the transgenic animals would overwhelm this machinery. If the human apo-B mRNA saturated the apo-B editing machinery, one might expect to find decreased editing of the mouse apo-B mRNA in the transgenic animals compared with the nontransgenic mice. This was not the case: the amount of editing of the mouse apo-B mRNA in the liver was virtually identical in the transgenic and nontransgenic animals, regardless of whether the animals were fed the chow or the high-fat diet (Table II). We were unable to detect an effect of the high-fat diet on the extent of apo-B mRNA editing; neither could we detect different extents of editing in animals that had been fasted for $14 \mathrm{~h}$ before death compared with animals that had been fasted for only $1 \mathrm{~h}$ before death.

For seven animals in each of the four groups of mice, we measured mouse apo-B levels, using a rocket immunoassay that was specific for mouse apo-B. The mouse apo-B levels in both the chow-fed transgenic and nontransgenic mice were 10-15 $\mathrm{mg} / \mathrm{dl}$; on a high-fat diet, the mouse apo-B levels approximately doubled in both transgenic and nontransgenic mice.

Lipid levels and lipid distribution. In this study, we measured lipid and lipoprotein levels in 24 transgenic females, 6 transgenic males, 24 nontransgenic females, and 6 nontransgenic males, on both the chow diet and the high-fat diet. Table I shows the lipid and lipoprotein levels in the transgenic and nontransgenic mice on the two diets, and provides statistical comparisons between the levels in male and female mice. Fig. 2 illustrates the differences in lipid and lipoprotein levels in the female transgenic and nontransgenic mice, and provides statistical comparisons between the levels observed. In considering the large amount of data presented in Table I and Fig. 2, several findings should be underscored. First, we found that the total and non-HDL cholesterol levels were significantly higher in the transgenic animals than in the nontransgenic animals, on both the chow diet and the high-fat diet. For example, in female transgenic animals on the high-fat diet, the mean total cholesterol level was $312 \mathrm{mg} / \mathrm{dl}$, compared with $230 \mathrm{mg} / \mathrm{dl}$ in the nontransgenic animals $(P=0.0025)$. Second, in response to the high-fat diet, the total and non-HDL cholesterol levels increased more in the female transgenic animals than in the female nontransgenic animals. For example, on the high-fat diet, the mean 
A Anti-human Apo-B

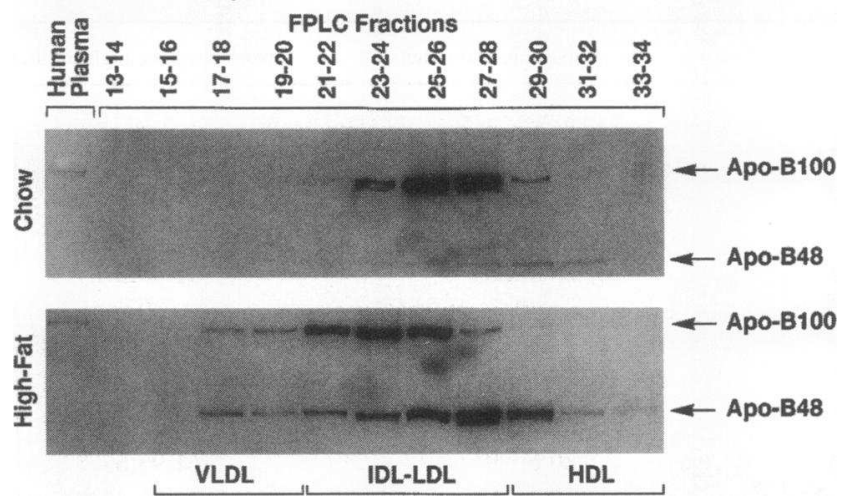

B Anti-mouse Apo-B
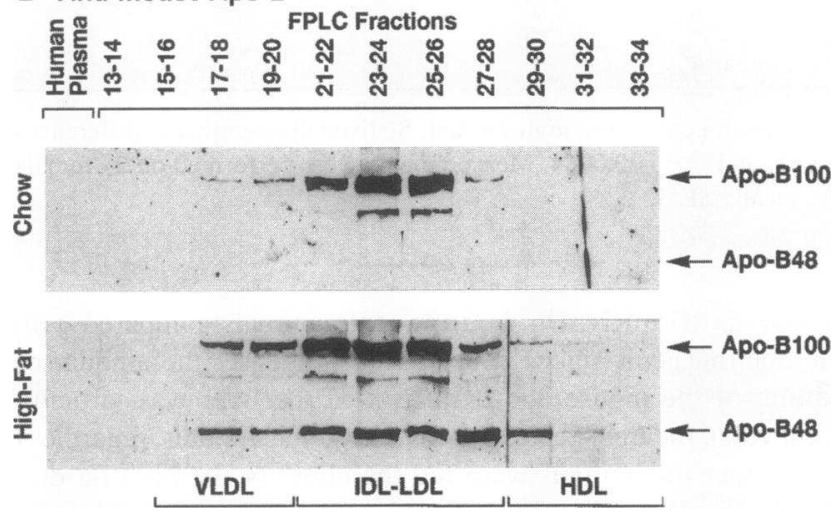

Figure 1. Western blot demonstrating the distribution of human and mouse apo-B48 and apo-B100 in the plasma of the human apo-B transgenic mice. Plasma was pooled from six mice that had been on either the chow or the high-fat diet for $5 \mathrm{wk} ; 120 \mu \mathrm{l}$ of the pooled plasma sample was subjected to size-fractionation on a Superose 6 column. Consecutive fractions were combined and electrophoresed on $3-12 \%$ gradient SDS-polyacrylamide gels; western blots were then performed using a human apo-B-specific monoclonal antibody, C1.4 $(A)$, or a rabbit antibody to mouse apo-B $(B)$. On two occasions, we performed an identical Western blot analysis to assess the distribution of apo-E in the transgenic and nontransgenic mice on the high-fat diet, using a rabbit antiserum to rat apo-E (kindly provided by $\mathrm{K}$. Weisgraber at the Gladstone Institute of Cardiovascular Disease). For both transgenic and nontransgenic mice, most $(>85 \%)$ of the apo-E was in fractions 17-24. The transgenic mice had slightly lower amounts of apo-E in fractions $31-36$, compared to the nontransgenic mice.

non-HDL cholesterol level in the transgenic mice was $91 \mathrm{mg} /$ dl higher than that of the nontransgenic mice; on the chow diet, it was only $49 \mathrm{mg} / \mathrm{dl}$ higher than in the nontransgenic mice. Third, the HDL cholesterol levels in the female transgenic mice were slightly but significantly lower (by $\sim 8 \mathrm{mg} / \mathrm{dl}$ ) compared with the female nontransgenic mice. The lower HDL cholesterol levels in the transgenic mice were observed on both diets. Fourth, on either diet, the male transgenic and nontransgenic animals had higher HDL cholesterol levels than the female animals. Fifth, the triglyceride levels were higher in the transgenic mice than in the nontransgenic mice, but only on the chow diet. On the high-fat diet, the triglyceride levels were low and there were no differences between the transgenic and nontransgenic mice. The low triglyceride levels on the high-fat
Table II. Apo-B mRNA Editing in Transgenic and Nontransgenic Mice

\begin{tabular}{|c|c|c|c|c|c|}
\hline Transgenic & Fasted & Diet & Organ & Mouse editing & Human editing \\
\hline \multicolumn{6}{|l|}{$n=3$} \\
\hline \multirow{3}{*}{+} & \multirow{3}{*}{ Yes } & \multirow{3}{*}{ Chow } & Intestine & $89.9 \pm 2.7$ & ND \\
\hline & & & Kidney & $39.5 \pm 5.0$ & $23.9 \pm 1.4$ \\
\hline & & & Liver & $64.4 \pm 5.3$ & $65.2 \pm 0.4$ \\
\hline \multirow{3}{*}{+} & \multirow{3}{*}{ Yes } & \multirow{3}{*}{ High-fat } & Intestine & $95.4 \pm 0.6$ & ND \\
\hline & & & Kidney & $39.2 \pm 4.1$ & $20.5 \pm 3.7$ \\
\hline & & & Liver & $62.5 \pm 6.1$ & $65.7 \pm 2.3$ \\
\hline \multirow{3}{*}{+} & \multirow{3}{*}{ No } & \multirow{3}{*}{ Chow } & Intestine & $91.4 \pm 1.1$ & ND \\
\hline & & & Kidney & $33.6 \pm 3.1$ & $26.3 \pm 3.6$ \\
\hline & & & Liver & $69.4 \pm 3.1$ & $65.2 \pm 3.5$ \\
\hline \multirow{3}{*}{+} & \multirow{3}{*}{ No } & \multirow{3}{*}{ High-fat } & Intestine & $93.1 \pm 2.2$ & ND \\
\hline & & & Kidney & $31.7 \pm 4.5$ & $29.2 \pm 0.8$ \\
\hline & & & Liver & $70.7 \pm 2.1$ & $66.7 \pm 2.4$ \\
\hline \multirow{3}{*}{ - } & \multirow{3}{*}{ Yes } & \multirow{3}{*}{ Chow } & Intestine & $94.1 \pm 0.6$ & \\
\hline & & & Kidney & $32.8 \pm 6.4$ & NA \\
\hline & & & Liver & $67.2 \pm 1.9$ & \\
\hline \multirow{3}{*}{-} & \multirow{3}{*}{ Yes } & \multirow{3}{*}{ High-fat } & Intestine & $97.7 \pm 1.1$ & \\
\hline & & & Kidney & $31.3 \pm 0.2$ & NA \\
\hline & & & Liver & $62.1 \pm 1.0$ & \\
\hline \multirow{3}{*}{-} & \multirow{3}{*}{ No } & \multirow{3}{*}{ Chow } & Intestine & $93.7 \pm 0.4$ & \\
\hline & & & Kidney & $26.4 \pm 1.9$ & NA \\
\hline & & & Liver & $64.9 \pm 2.5$ & \\
\hline \multirow{3}{*}{-} & \multirow{3}{*}{ No } & \multirow{3}{*}{ High-fat } & Intestine & $94.2 \pm 0.7$ & \\
\hline & & & Kidney & $30.3 \pm 3.6$ & NA \\
\hline & & & Liver & $65.1 \pm 5.7$ & \\
\hline
\end{tabular}

The percent editing of the human and mouse apo-B mRNA were performed as previously described (27). The values shown represent the mean $\pm S E M$ for three mice in each group. ND, not determined because the human apo-B transgene is not expressed in the mouse intestine; NA, not applicable.

diet is characteristic of the synthetic high-fat diet that was used in this study $(30,31)$.

To determine the distribution of cholesterol within the plasma lipoproteins, plasma samples were fractionated by Superose 6 chromatography. Consistent with our earlier studies on the distribution of cholesterol in the human apo-B transgenic founders (16), we found that the female transgenic mice on the chow diet had a marked increase in LDL cholesterol compared with the nontransgenic animals (Fig. 3). The amount of LDL cholesterol in the plasma of the transgenic mice on the highfat diet was much higher than in the nontransgenic mice; it was also higher than the amount of LDL cholesterol in the plasma of transgenic mice on the chow diet (Fig. 3). The chromatography studies confirmed the decrease in HDL cholesterol levels in the transgenic animals. The increase in VLDL cholesterol in the transgenic mice on the high-fat diet was similar to that observed in the nontransgenic mice. Consistent with these findings, we observed increased amounts of the pre- $\beta$-migrating lipoproteins 

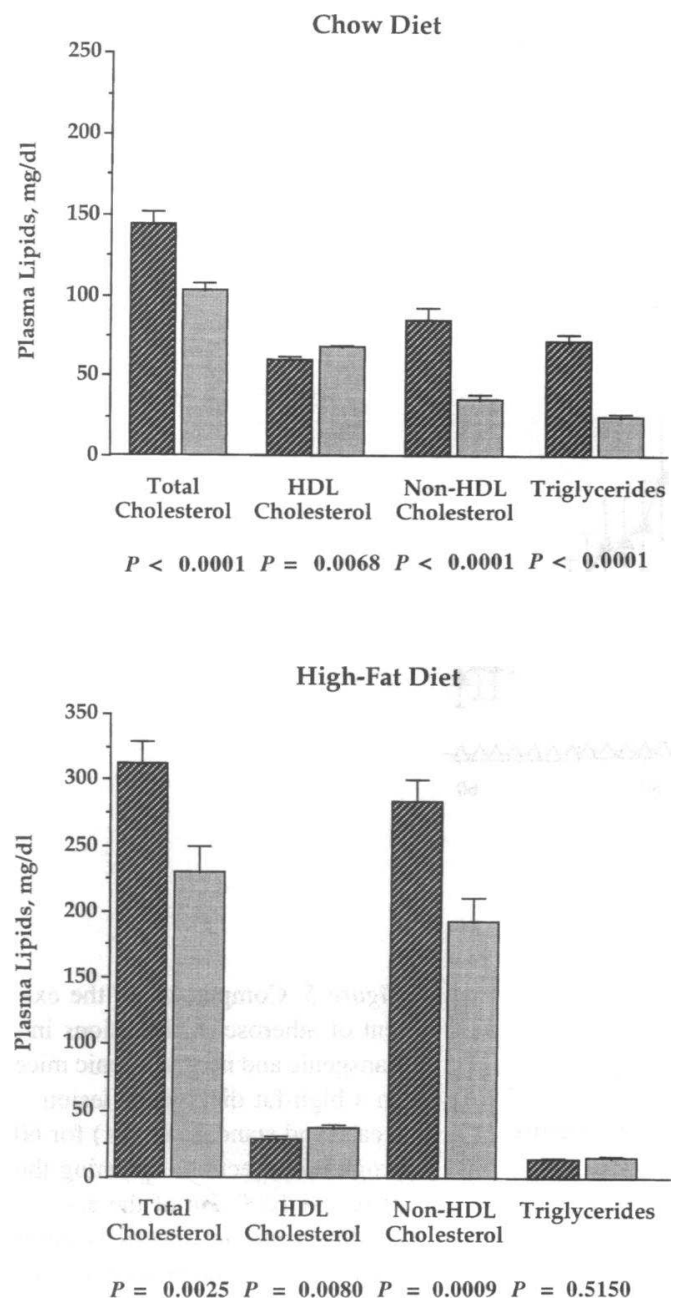

Figure 2. Comparison of lipid and lipoprotein levels in female human apo-B transgenic ( $\square)$ and nontransgenic ( $\square)$ littermates on a chow diet (top) and a high-fat diet (bottom).

on the high-fat diet in both transgenic and nontransgenic animals (Fig. 4).

Superose 6 cholesterol distribution profiles were also performed on male transgenic and nontransgenic mice. In keeping with the lower human apo-B levels in male transgenic mice, we found that the male mice had $20-30 \%$ lower LDL cholesterol peaks than the females, on both the chow and the highfat diets (data not shown).

Quantification of atherosclerosis in the proximal ascending aorta. To assess the degree of atherosclerosis in the transgenic and nontransgenic mice, we used a computer-assisted image analysis system to quantify the atherosclerotic lesions within each of 60 progressive sections spanning the proximal 1,200 $\mu \mathrm{m}$ of the ascending aorta. On a chow diet, neither the transgenic nor the nontransgenic mice had significant atherosclerotic lesions. In these animals, the mean lesion area was $<200 \mu \mathrm{m}^{2}$ per section. On the high-fat diet, the nontransgenic females had small atherosclerotic lesions, and most of these were confined to the proximal $400 \mu \mathrm{m}$ of the aorta (Fig. $5 \mathrm{~A}$ ). In contrast, the transgenic animals had extensive atherosclerotic lesions, extending throughout the proximal $1,200 \mu \mathrm{m}$ of the
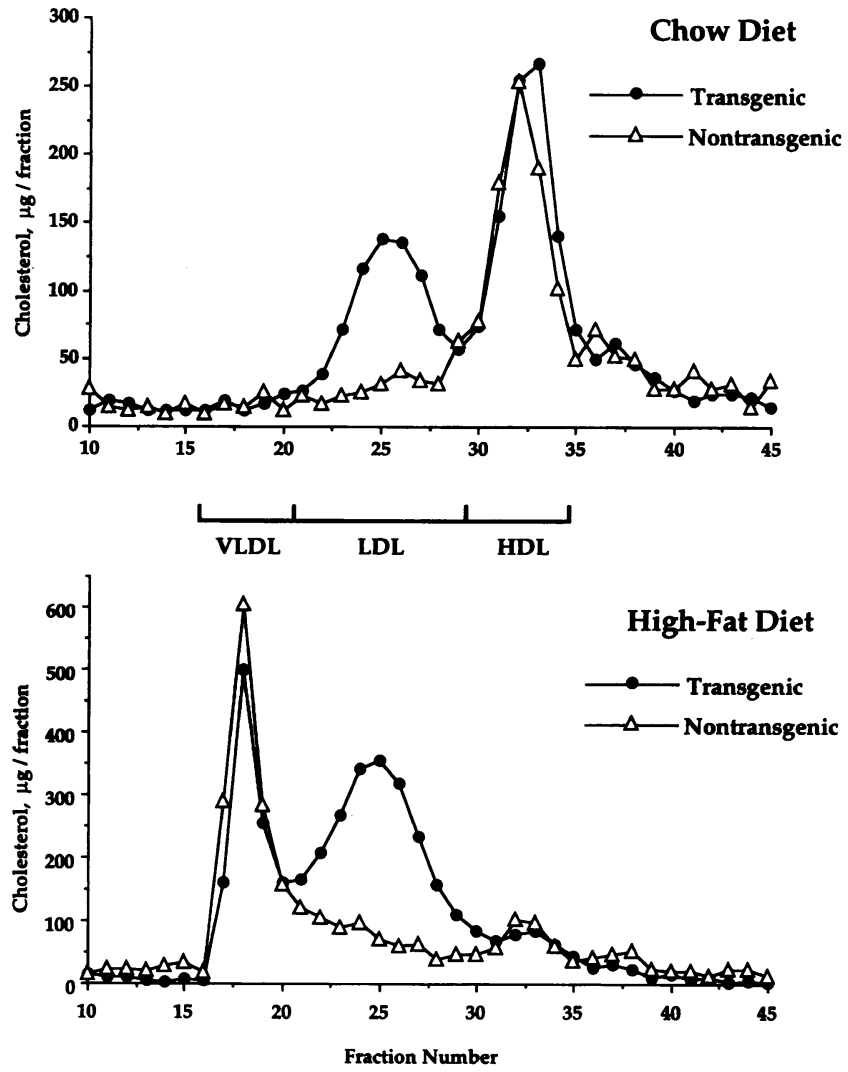

Figure 3. Distribution of cholesterol in the plasma of female human apo-B transgenic mice and nontransgenic mice, as assessed by Superose 6 chromatography, on a chow diet (top) and a high-fat diet (bottom).

aorta (Fig. $5 \mathrm{~A}$ ). The mean lesion area per section in the female transgenic mice was $163,158 \pm 3,489 \mu \mathrm{m}^{2}$, whereas it was $14,580 \pm 1,179 \mu \mathrm{m}^{2}$ in the female nontransgenic mice $(P$ $<0.0001)$. The atherosclerotic lesions in the male mice were smaller than those in females, but the male transgenic mice still had larger lesion areas than the male nontransgenic mice $\left(45,522 \pm 8,877 \mu \mathrm{m}^{2}\right.$ vs $\left.8,191 \pm 681 \mu \mathrm{m}^{2} ; P<0.05\right)$ (Fig. $5 B$ ).

\begin{tabular}{|r|c|c|c|c|}
\hline Transgene & + & + & - & - \\
\hline Diet & hf & ch & hf & ch \\
\hline
\end{tabular}

Figure 4. Agarose gel electrophoresis of plasma from transgenic and nontransgenic mice. $1 \mu \mathrm{l}$ of plasma from transgenic and nontransgenic mice on the chow and high-fat diets was electrophoresed on Corning $1 \%$ agarose gels. The gel was stained with Fat Red 7B. 


\section{A Females}

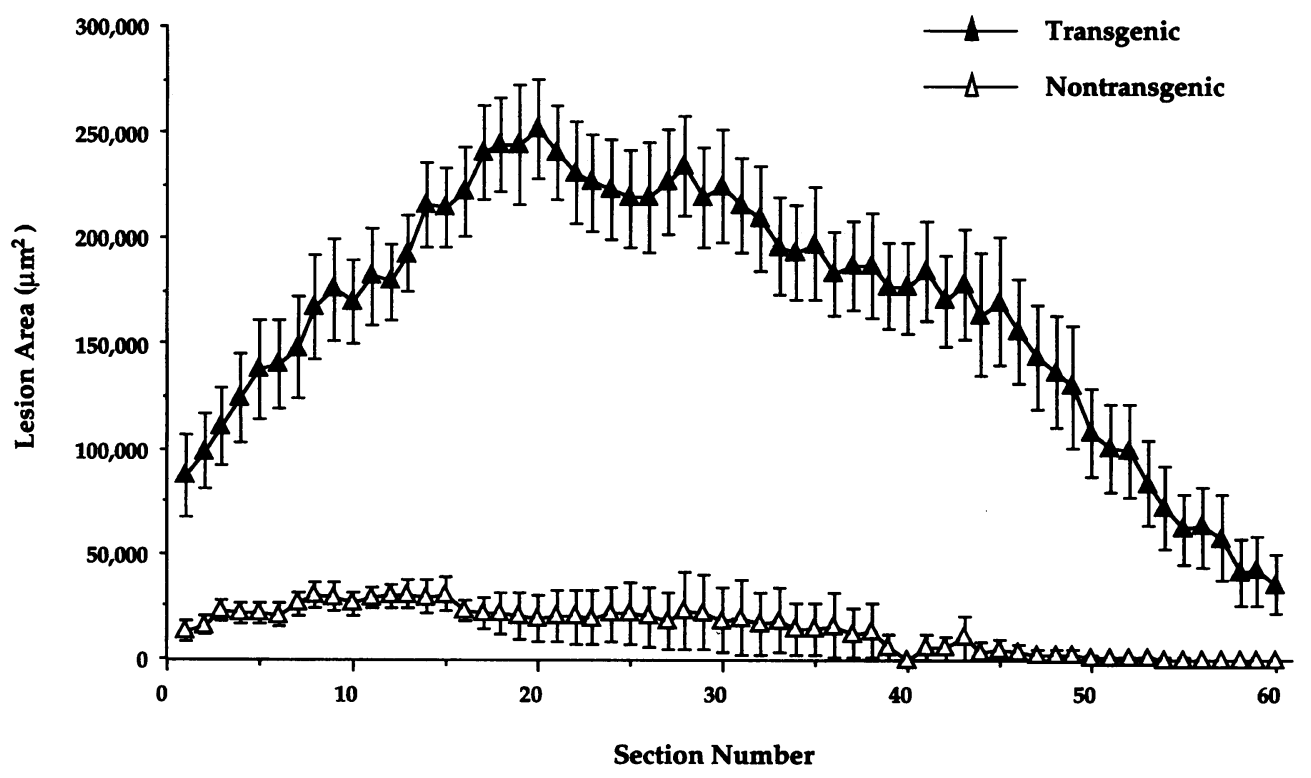

\section{B Males}

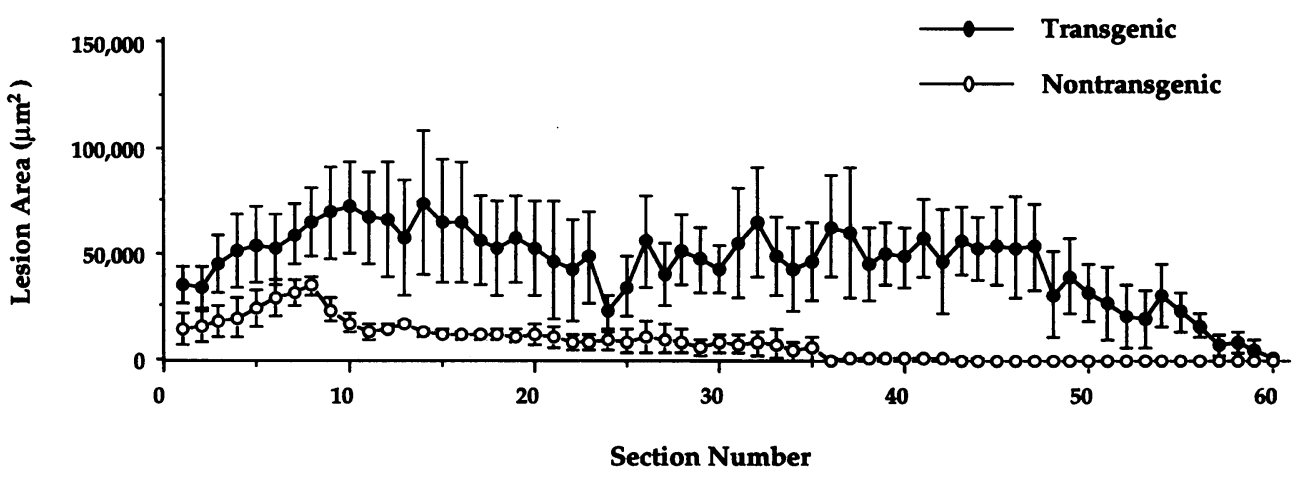

Figure 5. Comparison of the extent of atherosclerotic lesions in transgenic and nontransgenic mice on a high-fat diet. Mean lesion areas (and standard errors) for 60 progressive sections spanning the proximal $1200 \mu \mathrm{m}$ of the ascending aorta are shown. Section number 1 is in the proximal aortic sinus where the aortic valve leaflets first appeared (see Methods). $A$ shows the lesion data for the female transgenic and nontransgenic mice $(n=12) ; B$ shows the lesion data for the male mice $(n=5)$.
Fig. 6 shows typical Oil Red O-stained sections from the female nontransgenic mice (Fig. 6, $A$ and $C$ ) and female transgenic mice (Fig. $6, B$ and $D$ ), from the region near the aortic valve (section 21 ) and from further up the ascending aorta (section $\mathbf{4 4}$ in the transgenic animal and 33 in the nontransgenic animal). The lesions were fatty-streak lesions; no obvious fibrous caps were observed. (The lack of fibrous caps was not surprising; apo-E-deficient mice, which have much higher cholesterol levels, do not begin to develop fibrous caps until 1521 wk $[14,15]$.) Fig. $7 A$ shows a hematoxylin and eosinstained section from the aorta of a transgenic animal. Within the lesion, unstained voids can be observed, which, when stained with Masson's trichrome, prove to be collagenous connective tissue (Fig. $7 \mathrm{~B}$ ). Fig. 8 is a photomicrograph of a lesion from one of the transgenic animals, showing foam cells and abundant cholesterol crystals. The electron micrograph in Fig. 9, in addition to showing foam cells and cholesterol crystals at higher resolution, clearly reveals the endothelial cells.

\section{Discussion}

In this study, we characterized the plasma lipid, apo-B, and lipoprotein levels in human apo-B transgenic mice on chow and high-fat diets and examined the susceptibility of these mice to aortic atherosclerotic lesions. The genetic background of the mice was predominantly C57BL/6, a strain that has been shown to be susceptible to aortic atherosclerosis in response to a highfat diet $(5,32)$. The line of transgenic mice used in this study expressed high levels of human apo-B; chow-fed transgenic animals had human apo-B100 plasma levels that were nearly as high as those in normolipidemic humans and had substantially increased amounts of LDL cholesterol in the plasma. Despite the relatively high plasma levels of human apo-B100 and LDL cholesterol, the transgenic mice that were fed a chow diet for 18 wk did not develop aortic atherosclerotic lesions. On a highfat diet, however, the female transgenic mice developed extensive lipid-rich atherosclerotic lesions. These lesions were found 
A
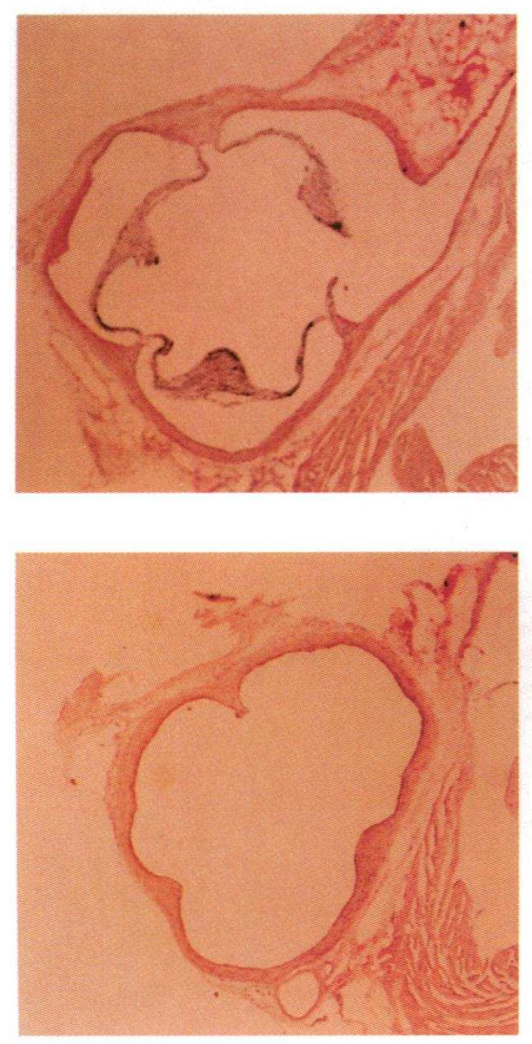

C
B
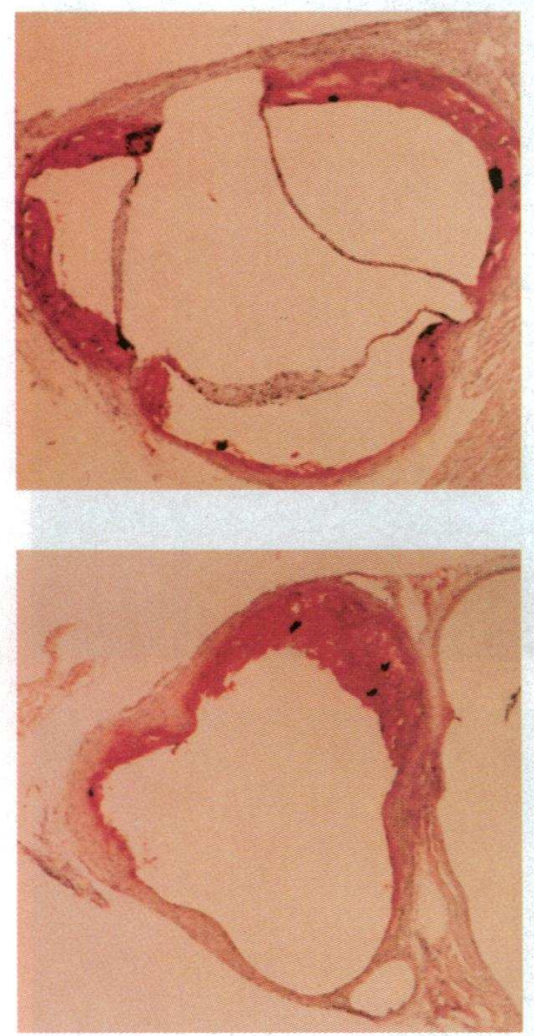

Figure 6. Oil Red O-stained sections of the thoracic aortas of female transgenic and nontransgenic animals after 18 wk of a high-fat diet. $A$ shows a section from a nontransgenic female in the distal region of the aurtic sinus (section number 21 ); (B) section 21 from a transgenic female; $(C)$ a section from a nontransgenic female from a more distal region of the ascending aorta (section 33 ); (D) section 44 from a transgenic female. $\times 34$. throughout the proximal $1,200 \mu \mathrm{m}$ of the ascending aorta and were frequently circumferential. In contrast, the lesions in the female nontransgenic mice fed the high-fat diet were small and largely confined to the aortic sinuses near the aortic valve.

The virtual absence of atherosclerotic lesions in the apo-B transgenic animals on the chow diet contrasts with the relatively severe lesions observed in apo-E-deficient mice on a chow diet $(10,12,14,15)$. The susceptibility of chow-fed apo-E-deficient mice to atherosclerosis may relate to their much higher total plasma cholesterol levels $(400-600 \mathrm{mg} / \mathrm{dl})$, the marked accumulation of VLDL-IDL cholesterol in their plasma, or the fact that those mice have marked reductions in HDL cholesterol levels $(12,33)$. The virtual absence of atherosclerosis in the chow-fed human apo-B transgenic mice is, however, consistent with the pathologic studies of LDL receptor-deficient mice (13), which, on a chow diet, have total plasma cholesterol levels of $\sim 250 \mathrm{mg} / \mathrm{dl}$ and relatively normal HDL cholesterol levels. After 12 mo on a chow diet, the LDL receptor-deficient mice had only small accumulations of foam cells within the aortic sinuses (13). Several factors might be important in explaining the absence of atherosclerotic lesions in the chow-fed human apo-B transgenic mice. High-fat diets are known to induce various inflammatory genes, and this induction may be important in atherogenesis (22). On a chow diet, in the absence of the induction of inflammatory genes, it is possible that the total cholesterol levels observed in the apo-B transgenic mice $(\sim 150 \mathrm{mg} / \mathrm{dl})$ are simply not high enough to initiate atherosclerosis, at least in an 18-wk time frame. In addition, it is possible that the relatively normal HDL cholesterol levels in the chow-fed apo-B transgenic mice may serve to protect these animals from atherosclerosis. To address this issue, we have recently generated mice that express both human apo-B and human cholesteryl ester transfer protein (34); these mice do not have increased total cholesterol levels but show a striking reduction in HDL cholesterol levels and an LDL cholesterol:HDL cholesterol ratio of $\sim 2: 1$. If our future studies reveal that these mice develop atherosclerosis on a chow diet, it will add to the accumulating data $(33,35)$ that HDL play an important role in preventing murine atherosclerosis.

On a high-fat diet, the mean total cholesterol level in the female transgenic animals was $311 \mathrm{mg} / \mathrm{dl}$, only $\sim 80 \mathrm{mg} / \mathrm{dl}$ higher than the mean level in the nontransgenic animals; nevertheless, the transgenic animals had more than a 10-fold increase in atherosclerotic lesion area as compared to the nontransgenic animals. What is the likely reason for this marked difference in susceptibility to atherosclerosis? The amount of cholesterol in the VLDL fraction does not appear to explain it, as little difference was observed in the amount of VLDL cholesterol in the transgenic mice and nontransgenic mice (Fig. 2). However, the transgenic animals did have markedly increased amounts of cholesterol in the LDL fraction. In view of the abundant human and experimental animal data linking elevated LDL cholesterol levels to atherosclerosis (36), it is very difficult to avoid the conclusion that the increased amount of LDL cholesterol in the transgenic animals was the principal factor underlying the striking increase in atherosclerosis in those animals (Table I). 


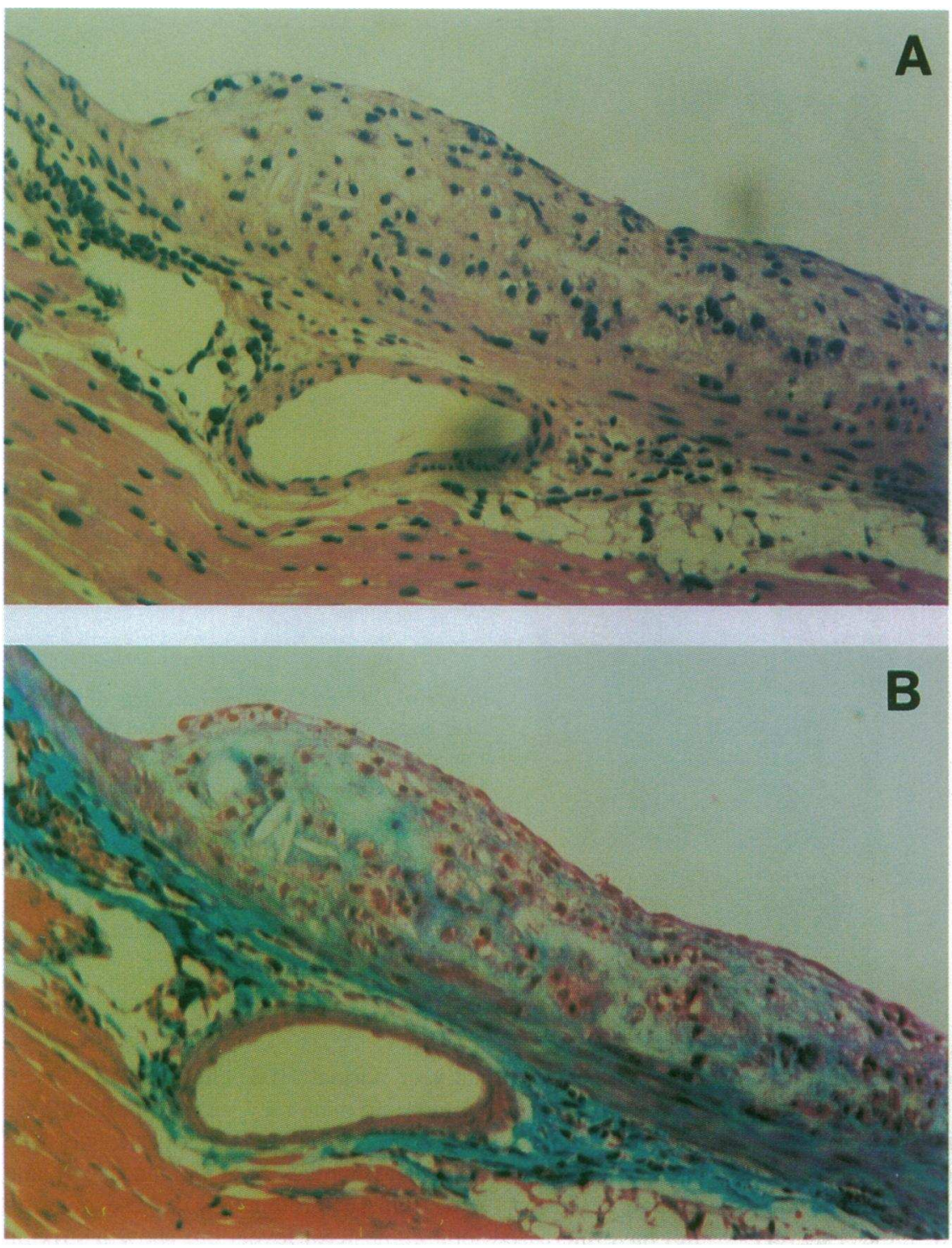

Figure 7. Hematoxylin and eosin-stained section $(A)$ and Masson's-trichrome-stained section $(B)$ of the thoracic aorta of a female transgenic mouse that was killed after 18 wk on the high-fat diet. In $B$, collagen is stained green. No fibrous cap is visible in this lesion, but connective tissue is visible within the necrotic core of the lesion. $\times 160$.
In addition to the increased amounts of LDL cholesterol in the transgenic animals, it is possible that the composition of the LDL was particularly atherogenic. In the chow-fed transgenic animals, the LDL was enriched in triglycerides (16). On the high-fat diet, the LDL contained large amounts of cholesteryl esters, but only small amounts of triglycerides. Furthermore, the human apo-B100 on the high-fat diet tended to be in somewhat larger particles. These large, cholesteryl ester-enriched LDL were probably atherogenic; large, cholesterol ester-enriched LDL appear to be quite atherogenic in monkeys (2).

A second factor that could have contributed to the atherosclerosis in the transgenic animals on the high-fat diet was decreased HDL cholesterol levels. Both the transgenic and nontransgenic animals had marked decreases in HDL cholesterol levels on the high-fat diet (a finding typical of C57BL/6 mice $[20,33])$, but the transgenic mice had significantly lower HDL cholesterol levels than the nontransgenic animals. Although the metabolism of HDL in the transgenic mice is not yet understood, it is quite possible that the low HDL cholesterol levels in the transgenic animals significantly contributed to their susceptibility to atherosclerosis.

Because the consumption of a high-fat diet causes elevated apo-B100 levels in primates $(2)$ and humans $(37,38)$, we found it interesting that the high-fat diet did not result in elevated levels of human apo-B100 in the transgenic mice. On the highfat diet, the total human apo-B levels increased by $44 \%$ in the female transgenic mice, but the increase was entirely explained by increased amounts of human apo-B48. The reason for the increased amounts of apo-B48 is not readily apparent, as we were unable to document a significantly increased level of hepatic apo-B mRNA editing on the high-fat diet. One possible explanation for the increased apo-B48 levels on the high-fat diet is that this diet increases the efficiency of secretion of newly synthesized apo-B48, but has little effect on the efficiency of apo-B100 secretion. Alternatively, it is possible that the highfat diet markedly retards apo-B48 clearance rates without changing the apo-B100 clearance rate. Whatever the mechanism, it appears to apply to both mouse apo-B48 and human 


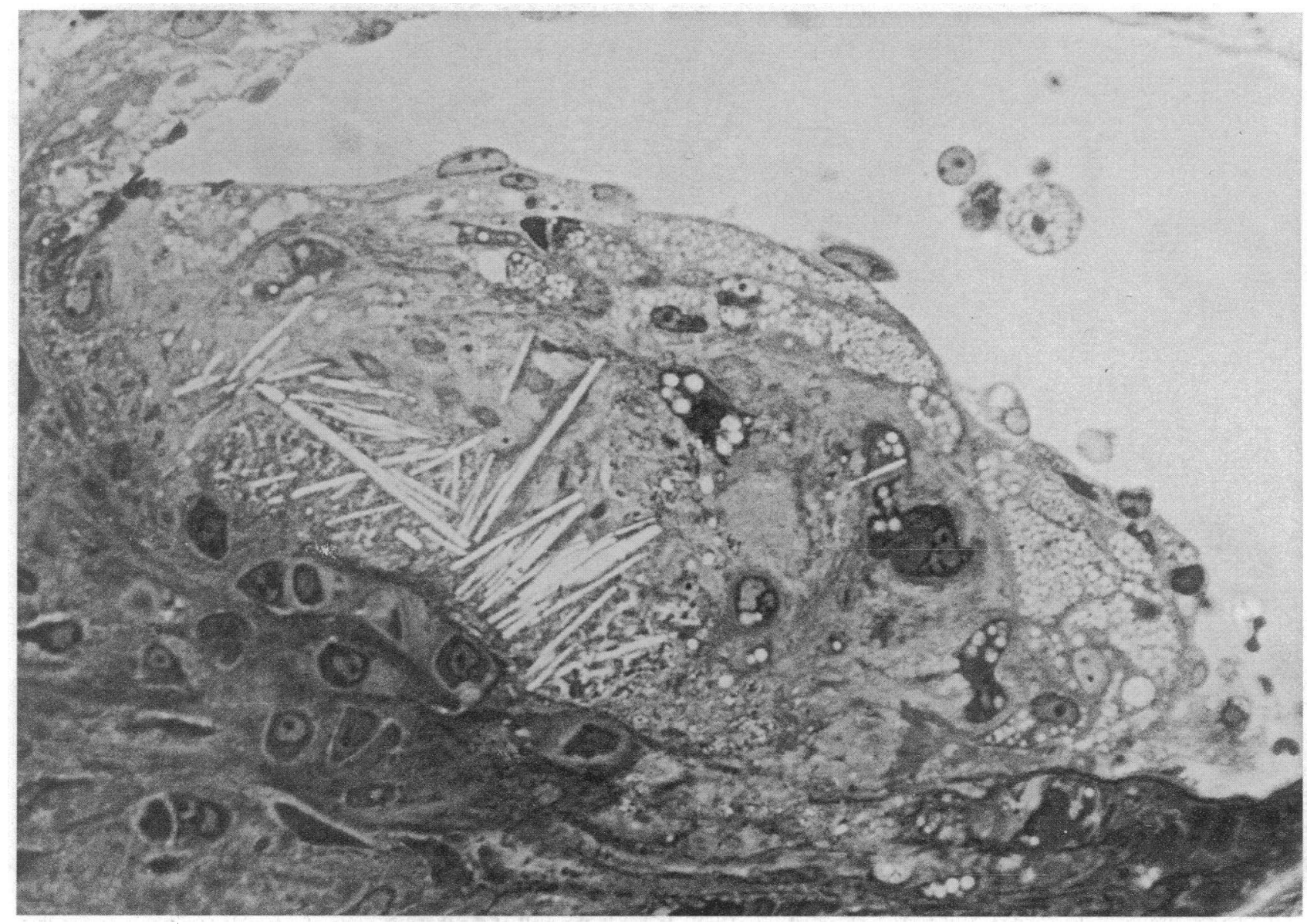

Figure 8. Photomicrograph of an atherosclerotic lesion in the wall of the thoracic aorta of a female transgenic mouse that was killed after 18 wk on a high-fat diet. The sections were cut from epoxy resin-embedded tissue and stained with toluidine blue. $\times 836$.

apo-B48, as we have documented that the amount of mouse apo-B48 also increased significantly on the high-fat diet. In a survey of plasma apo-B levels in various inbred strains of mice, Lusis et al. (4) found that a high-fat diet affects apo-B48 and apo-B100 levels differently in the different inbred strains. In C57BL/ 6 mice, apo-B48 levels increased on a high-fat diet; however, the increase in apo-B48 was not observed in some of the other inbred strains. Because of these findings, we consider it likely that certain aspects of the lipoprotein phenotype associated with the human apo-B transgene (e.g., relative levels of apo-B48 and apo-B100 on different diets) would differ depending upon the genetic background of the mice used in the experiment.

Although the mechanisms controlling the relative levels of apo-B48 and apo-B100 are not fully understood, our experiments indicated that the human apo- $\mathrm{B}$ transgenic mice on the high-fat diet have roughly equal amounts of apo-B48 and apoB100 in their LDL-sized lipoproteins. Based on reports of the phenotypes of genetically altered mice $(10,12-15)$, it is our opinion that both apo-B48-containing and apo-B100-containing lipoproteins are atherogenic. The results of this study do not permit us to dismiss the possibility that the high levels of LDL-apo-B48 on the high-fat diet are particularly important in contributing to the development of atherosclerosis. At present, we have no experimental data addressing the relative ath- erogenicities of the apo-B48- and apo-B100-containing lipoproteins. In the future, however, we do expect to be able to address this issue, using recently generated mice that synthesize exclusively apo-B48 (apo-B48-only mice) or exclusively apoB100 (apo-B100-only mice) (Farese, R. V., Jr., and S. G. Young, unpublished observations ).

In this study, the atherosclerotic lesions were rigorously quantified by computerized techniques. Images of each of the sections were obtained with a video camera attached to a light microscope; the images were stored on an optical disk, where they could be retrieved easily and reviewed for their accuracy. We believe that this computerized lesion quantification system greatly minimizes the subjectivity and technical errors that can occur when lesions are quantified manually, using a counting grid within the eyepiece on the microscope. In addition, it is noteworthy that we examined a considerably larger sample of sections per unit length than has been done in most previous studies of mouse atherosclerosis, where as few as four sections (per animal) have been analyzed $(39,40)$. This thorough pathologic examination allowed us to document that the difference in the extent of lesions between transgenic and nontransgenic mice depends upon the distance of the sections. For example, whereas the transgenic females had sevenfold more lesions within the proximal $400 \mu \mathrm{m}$ of the aorta, they had 46-fold more lesions between $800 \mu \mathrm{m}$ and $1,200 \mu \mathrm{m}$ from the aortic valve. 


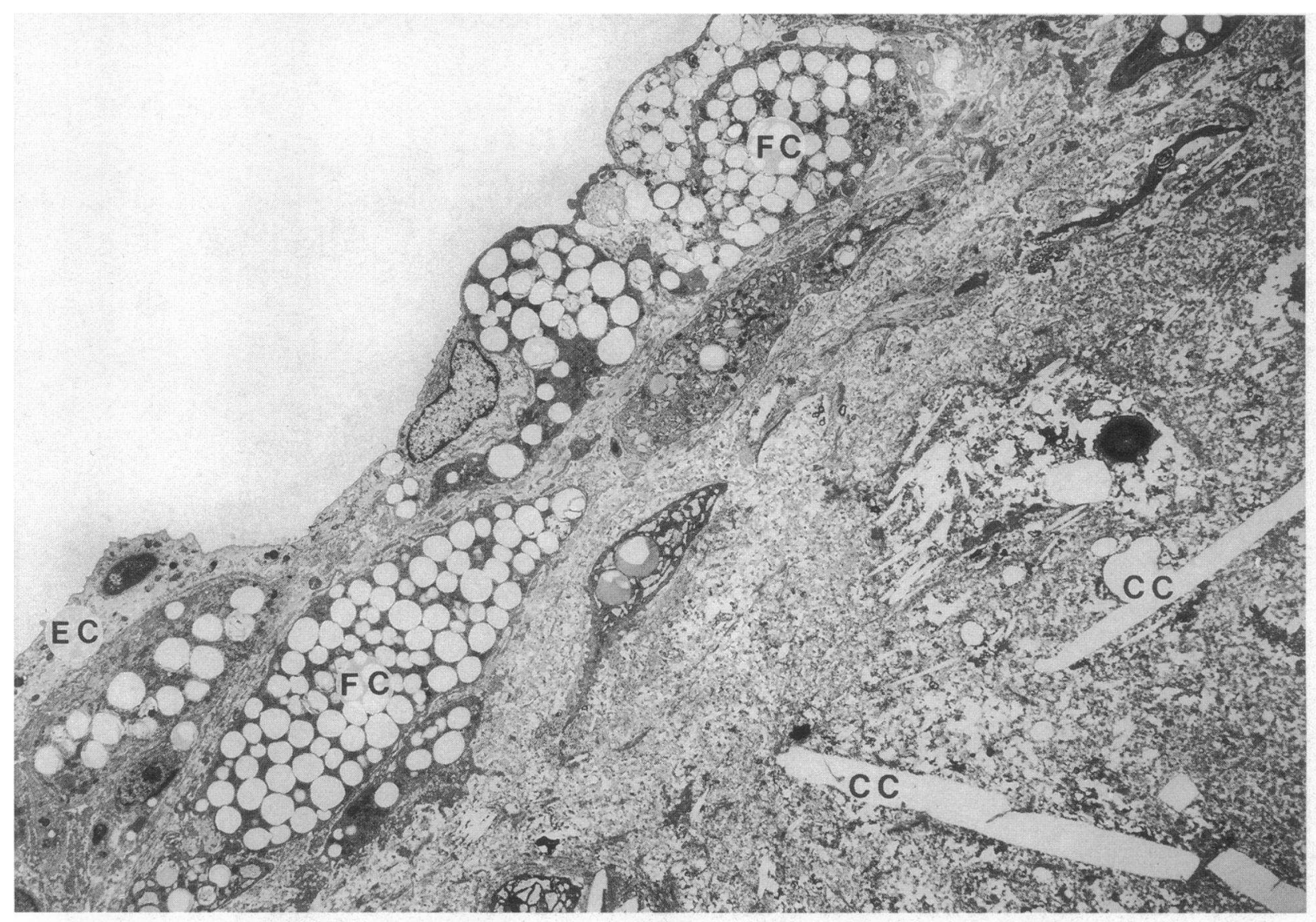

Figure 9. Electron micrograph of a thin section through an atherosclerotic lesion in the wall of the thoracic aorta of a female transgenic mouse that was killed after 18 wk on a high-fat diet. EC, endothelial cell; FC, foam cell; CC, cholesterol crystal cleft. $\times 2,650$.

In summary, we have shown that human apo-B transgenic mice develop high plasma levels of LDL cholesterol and severe atherosclerotic lesions in response to a high-fat diet. These findings occur in the hemizygous state, in contrast to findings in the LDL-receptor knockout or apo-E knockout mice, which must be bred to homozygosity to demonstrate the dramatic lipoprotein phenotype and the severe atherosclerotic lesions. While each of these mouse models is of obvious importance for future genetic and pathologic studies, the dominant phenotype of the human apo-B transgenic mice will undoubtedly prove useful for certain types of genetic studies. For example, in studies designed to identify the effects of other transgenes on atherogenesis in the mouse, or to identify new genes involved in atherogenesis, the use of an animal model with a dominant phenotype would reduce the number of matings required to set up an experiment and observe an effect.

\section{Acknowledgments}

We would like to thank H. Hobbs for the antiserum to mouse apo-B, $\mathrm{K}$. Weisgraber for the antibody to rat apo-E, L. Curtiss for antibody MB47, R. Milne for antibody 1D1, G. Melchior for measuring mouse apo-B levels, L. Hymowitz for preparation of the manuscript, D. Levy for editorial assistance, and L. Jach for graphics.

Supported by National Institutes of Health grant HL-41633.

\section{References}

1. Young, S. G. 1990. Recent progress in understanding apolipoprotein B. Circulation. 82:1574-1594.

2. Carr, T. P., J. S. Parks, and L. L. Rudel. 1992. Hepatic ACAT activity in African green monkeys is highly correlated to plasma LDL cholesteryl ester enrichment and coronary artery atherosclerosis. Arterioscler. Thromb. 12:12741283.

3. Wolfe, M. S., J. S. Parks, T. M. Morgan, and L. L. Rudel. 1993. Childhood consumption of dietary polyunsaturated fat lowers risk for coronary artery atherosclerosis in African green monkeys. Arterioscler. Thromb. 13:863-875.

4. Lusis, A. J., B. A. Taylor, D. Quon, S. Zollman, and R. C. LeBoeuf. 1987. Genetic factors controlling structure and expression of apolipoproteins $B$ and $E$ in mice. J. Biol. Chem. 262:7594-7604.

5. Ishida, B. Y., and B. Paigen. 1989. Atherosclerosis in the mouse. In Genetic Factors in Atherosclerosis: Approaches and Model Systems. A. J. Lusis and S. R. Sparkes, editors. S. Karger AG, Basel, Switzerland. 189-222.

6. Mahley, R. W. 1988. Apolipoprotein E: cholesterol transport protein with expanding role in cell biology. Science (Wash. DC). 240:622-630.

7. Innerarity, T. L., R. W. Mahley, K. H. Weisgraber, T. P. Bersot, R. M. Krauss, G. L. Vega, S. M. Grundy, W. Friedl, J. Davignon, and B. J. McCarthy. 1990. Familial defective apolipoprotein B100: a mutation of apolipoprotein B that causes hypercholesterolemia. J. Lipid Res. 31:1337-1349.

8. Brown, M. S., and J. L. Goldstein. 1986. A receptor-mediated pathway for cholesterol homeostasis. Science (Wash. DC). 232:34-47.

9. Piedrahita, J. A., S. H. Zhang, J. R. Hagaman, P. M. Oliver, and N. Maeda. 1992. Generation of mice carrying a mutant apolipoprotein $E$ gene inactivated by gene targeting in embryonic stem cells. Proc. Natl. Acad. Sci. USA. 89:44714475.

10. Plump, A. S., J. D. Smith, T. Hayek, K. Aalto-Setälä, A. Walsh, J. G. Verstuyft, E. M. Rubin, and J. L. Breslow. 1992. Severe hypercholesterolemia and atherosclerosis in apolipoprotein $\mathrm{E}$-deficient mice created by homologous recombination in ES cells. Cell. 71:343-353. 
11. Ishibashi, S., M. S. Brown, J. L. Goldstein, R. D. Gerard, R. E. Hammer and J. Herz. 1993. Hypercholesterolemia in low density lipoprotein recepto knockout mice and its reversal by adenovirus-mediated gene delivery. J. Clin. Invest. 92:883-893.

12. Zhang, S. H., R. L. Reddick, J. A. Piedrahita, and N. Maeda. 1992 Spontaneous hypercholesterolemia and arterial lesions in mice lacking apolipoprotein E. Science (Wash. DC). 258:468-471.

13. Ishibashi, S., J. L. Goldstein, M. S. Brown, J. Herz, and D. K. Burns 1994. Massive xanthomatosis and atherosclerosis in cholesterol-fed low density lipoprotein receptor-negative mice. J. Clin. Invest. 93:1885-1893.

14. Nakashima, Y., A. S. Plump, E. W. Raines, J. L. Breslow, and R. Ross 1994. ApoE-deficient mice develop lesions of all phases of atherosclerosis throughout the arterial tree. Arterioscler. Thromb. 14:133-140.

15. Reddick, R. L., S. H. Zhang, and N. Maeda. 1994. Atherosclerosis in mice lacking apo E. Evaluation of lesional development and progression. Arterioscler. Thromb. 14:141-147.

16. Linton, M. F., R. V. Farese, Jr., G. Chiesa, D. S. Grass, P. Chin, R. E Hammer, H. H. Hobbs, and S. G. Young. 1993. Transgenic mice expressing high plasma concentrations of human apolipoprotein B100 and lipoprotein(a). J. Clin. Invest. 92:3029-3037.

17. Young, S. G., R. V. Farese, Jr., V. R. Pierotti, S. Taylor, D. S. Grass, and M. F. Linton. 1994. Transgenic mice expressing human $a_{p o B} B_{100}$ and $a_{0 p o B} B_{48}$ Curr. Opin. Lipidol. 5:94-101.

18. Davidson, N. O. 1994. RNA editing of the apolipoprotein B gene. A mechanism to regulate the atherogenic potential of intestinal lipoproteins? Trends Cardiovasc. Med. 4:231-235.

19. Ishida, B. Y., P. J. Blanche, A. V. Nichols, M. Yashar, and B. Paigen. 1991. Effects of atherogenic diet consumption on lipoproteins in mouse strains C57BL/6 and C3H. J. Lipid Res. 32:559-568.

20. Paigen, B., D. Mitchell, K. Reue, A. Morrow, A. J. Lusis, and R. C. LeBoeuf. 1987. Ath-l, a gene determining atherosclerosis susceptibility and high density lipoprotein levels in mice. Proc. Natl. Acad. Sci. USA. 84:3763-3767.

21. LeBoeuf, R. C., M. H. Doolittle, A. Montcalm, D. C. Martin, K. Reue and A. J. Lusis. 1990. Phenotypic characterization of the Ath-l gene controlling high density lipoprotein levels and susceptibility to atherosclerosis. J. Lipid Res. 31:91-101.

22. Liao, F., A. Andalibi, F. C. deBeer, A. M. Fogelman, and A. J. Lusis 1993. Genetic control of inflammatory gene induction and NF- $\kappa$ B-like transcription factor activation in response to an atherogenic diet in mice. J. Clin. Invest. 91:2572-2579.

23. Castle, C. K., J. R. Colca, and G. W. Melchior. 1993. Lipoprotein profile characterization of the $\mathrm{KKA}^{\mathrm{y}}$ mouse, a rodent model of type II diabetes, before and after treatment with the insulin-sensitizing agent pioglitazone. Arterioscler. Thromb. 13:302-309.

24. Young, S. G., S. J. Bertics, T. M. Scott, B. W. Dubois, L. K. Curtiss, and J. L. Witztum. 1986. Parallel expression of the MB19 genetic polymorphism in apoprotein B-100 and apoprotein B-48. Evidence that both apoproteins are products of the same gene. J. Biol. Chem. 261:2995-2998.

25. Krul, E. S., Y. Kleinman, M. Kinoshita, B. Pfleger, K. Oida, A. Law, J.
Scott, R. Pease, and G. Schonfeld. 1988. Regional specificities of monoclonal anti-human apolipoprotein B antibodies. J. Lipid Res. 29:937-947.

26. Pease, R. J., R. W. Milne, W. K. Jessup, A. Law, P. Provost, J.-C. Fruchart, R. T. Dean, Y. L. Marcel, and J. Scott. 1990. Use of bacterial expression cloning to localize the epitopes for a series of monoclonal antibodies against apolipoprotein B100. J. Biol. Chem. 265:553-568.

27. Chiesa, G., D. F. Johnson, Z. Yao, T. L. Innerarity, R. W. Mahley, S. G. Young, R. H. Hammer, and H. H. Hobbs. 1993. Expression of human apolipoprotein B100 in transgenic mice. Editing of human apolipoprotein B100 mRNA. $J$. Biol. Chem. 268:23747-23750.

28. Boström, K., Z. Garcia, K. S. Poksay, D. F. Johnson, A. J. Lusis, and T. L. Innerarity. 1990. Apolipoprotein B mRNA editing. Direct determination of the edited base and occurrence in non-apolipoprotein B-producing cell lines. $J$. Biol. Chem. 265:22446-22452.

29. Paigen, B., A. Morrow, P. A. Holmes, D. Mitchell, and R. A. Williams. 1987. Quantitative assessment of atherosclerotic lesions in mice. Atherosclerosis. 68:231-240.

30. Nishina, P. M., J. Verstuyft, and B. Paigen. 1990. Synthetic low and high fat diets for the study of atherosclerosis in the mouse. J. Lipid Res. 31:859-869.

31. LeBoeuf, R. C., M. Caldwell, and E. Kirk. 1994. Regulation by nutritional status of lipids and apolipoproteins A-I, A-II, and A-IV in inbred mice. J. Lipid Res. 35:121-133.

32. Paigen, B., B. Y. Ishida, J. Verstuyft, R. B. Winters, and D. Albee. 1990. Atherosclerosis susceptibility differences among progenitors of recombinant inbred strains of mice. Arteriosclerosis. 10:316-323.

33. Pászty, C., N. Maeda, J. Verstuyft, and E. M. Rubin. 1994. Apolipoprotein AI transgene corrects apolipoprotein $\mathrm{E}$ deficiency-induced atherosclerosis in mice. J. Clin. Invest. 94:899-903.

34. Grass, D. S., U. Saini, R. H. Felkner, S. G. Young, R. E. Wallace, T. D. Yeck, and M. E. Swanson. 1994. Transgenic mice expressing human apo B and human cholesteryl ester transfer protein have a lipoprotein-cholesterol profile similar to that of normolipidemic humans. Circulation. 90:134a. (Abstr.)

35. Rubin, E. M., R. M. Krauss, E. A. Spangler, J. G. Verstuyft, and S. M. Clift. 1991. Inhibition of early atherogenesis in transgenic mice by human apolipoprotein AI. Nature (Lond.). 353:265-267.

36. Consensus Conference. 1985. Lowering blood cholesterol to prevent heart disease. JAMA J. Am. Med. Assoc. 253:2080-2086.

37. Vega, G. L., E. Groszek, R. Wolf, and S. M. Grundy. 1982. Influence of polyunsaturated fats on composition of plasma lipoproteins and apolipoproteins J. Lipid Res. 23:811-822.

38. Mattson, F. H., and S. M. Grundy. 1985. Comparison of effects of dietary saturated, monounsaturated, and polyunsaturated fatty acids on plasma lipids and lipoproteins in man. J. Lipid Res. 26:194-202.

39. Lawn, R. M., D. P. Wade, R. E. Hammer, G. Chiesa, J. G. Verstuyft, and E. M. Rubin. 1992. Atherogenesis in transgenic mice expressing human apolipoprotein (a). Nature (Lond.). 360:670-672.

40. Marotti, K. R., C. K. Castle, T. P. Boyle, A. H. Lin, R. W. Murray, and G. W. Melchior. 1993. Severe atherosclerosis in transgenic mice expressing simian cholesteryl ester transfer protein. Nature (Lond.). 364:73-75. 